\title{
Problematika Pembelajaran Saat Pandemi Covid-19 Di Madrasah Ibtidaiyah Nurul Ulum Mertak Tombok
}

\author{
Mukminah $^{1}$, Hadi Wijaya ${ }^{2}$, Hirlan $^{3}$ \\ Email: Mukminah145@gmail.com, hadiwijaya.ntb@gmail.com, mrhirlan@gmail.com
}

\begin{abstract}
Abstrak . Penelitian ini bertujuan untuk mengidentifikasi implementasi pembelajaran daring dirumah pada siswa Sekolah Dasar akibat dari adanya pandemik Covid-19. Penelitian ini menggunakan penelitian kualitatif deskriptif dimana dalam mengumpulkan informasi/data dengan teknik observasi, dokumentasi, dan wawancara yaitu mencari data mengenai hal-hal yang relevan dengan pengimplementasiannya. Hasil penelitian dapat disimpulkan dilihat dari berbagai faktor yakni, 1) terbatasnya media pembelajaran daring seperti HP, Laptop, dan media pendukung lainnya. 2) Akses jaringan terbatas 3) kuota yang terbatas juga merupakan kendala bagi wali murid terkhusus lagi siswa untuk melakukan pembelajaran daring dikarenakan faktor ekonomi. Pembelajaran luring juga pelaksanaanya sangat minim karena media seperti TV, Radio, dan media lainnya sangat minim menyiarkan materi pembelajaran bagi siswa sekolah Dasar. KBM bisa terlaksana dengan kalaboratif pembelajaran luring dengan mendatangi peserta didik kerumahnya bersama orang tua membantu kegiatan pembelajaran dengan protokol kesehatan.
\end{abstract}

Kata Kunci: Problematika, Pembelajaran, Pandemi, Covid-19

\section{PENDAHULUAN}

Dewasa ini pembelajaran dibenturkan dengan berbagai aspek dengan perkembangan dan kendala yang dihadapi. Pembelajaran merupakan satu proses yang panjang agar mencapai hasil yang lebih. Untuk mencapai hasil ini diperlukan strategi yang tepat yakni melalui strategi pembelajaran. Strategi pembelajaran merupakan suatu cara atau metode yang dilakukan oleh pendidik terhadap anak didik dalam upaya terjadinya perubahan aspek kognitif, afektif, dan motorik secara berkesinambungan.

Azhar (2011) mengatakan pembelajaran adalah segala sesuatu yang dapat membawa informasi dan pengetahuan dalam interaksi yang berlangsung antara pendidik dengan peserta didik.

Perkembangan zaman pendidikan telah mengalamai tranformasi dari berbagai aspek dan sudut pandangnya. Perubahan yang terjadi telah dipengaruhi oleh iklim pendidikan yang sesuai dengan zamannya. Terlebih lagi ahir-ahir ini kita dihadapkan dengan situasi pendidikan yang sangat urgen dimana proses pembelajaran dari awal tahun 2020 pendidikan darurat dilaksanakan. Yakni proses pembelajaran yang dilakukan dengan menggunakan metode Daring. Metode daring saat ini tidak hanya berlaku untuk satu sekolah melainkan untuk semua jenjang pendidikan saat ini. Hal ini disebabkan oleh virus yang saat ini kita kenal dengan virus Corona atau Covid -19.

Pembelajaran daring yang diberlakukan oleh pemerintah bukan tanpa ada kendala dan kekurangan meskipun pada dasarnya pembelajaran daring bisa memberikan dampak positif terhadap kemajuan pendidikan saat ini. Namun pembelajaran daring yang dilaksanakan dibeberapa sekolah atau disemua jenjang pendidikan baik di tingkat yang paling bawah seprti TK, SD, SLTP, SLTA dan perguruan tinggi tidak semua bisa merasakan pembelajaran daring dengan maksimal. Pada dasarnya, metode pembelajaran daring tidak menuntut peserta didik untuk hadir dikelas. Peserta Didik akan mendapat materi pembelajaran dari guru-guru mereka melalui media onlie seperti What's Up (WA) atau media lainnya yang sesuai dengan kebutuhan dan kemampuan sekolah tersebut.

Berkaitan dengan adanya wabah Covid-19 pada awal tahun 2020, pemerintah kemudian mengeluarkan himbauan untuk melakukan kegiatan pembelajaran dari rumah (Fajrian, 2020). Hal ini dilakukan demi 
memutus rantai penyebaran virus dan menjaga keamanan serta keselamatan peserta didik dan tenaga pendidik. Dengan adanya himbauan tersebut maka proses pembelajaran pun dilakukan dari rumah dengan memanfaatkan teknologi dan media internet.

Pembelajaran yang dilasanakan di tingkat Sekolah Dasar juga menggunakan pembelajaran daring/jarak jauh dengan melalui bimbingan orang tua. Menurut Isman pembelajaran daring merupakan pemanfaatan jaringan internet dalam proses pembelajaran. Dengan pembelajaran daring siswa memiliki keleluasaan waktu belajar, dapat belajar kapanpun dan dimanapun. Siswa dapat berinteraksi dengan guru menggunakan beberapa aplikasi seperti classroom, video converence, telepon atau live chat, zoom maupun melalui whatsapp group. Pembelajaran ini merupakan inovasi pendidikan untuk menjawab tantangan akan ketersediaan sumber belajar yang variatif. Keberhasilan dari suatu model ataupun media pembelajaran tergantung dari karakteristik peserta didiknya. Sebagai mana yang diungkapkan oleh Nakayama bahwa dari semua literatur dalam e-learning mengindikasikan bahwa tidak semua peserta didik akan sukses dalam pembelajaran online. Ini dikarenakan faktor lingkungan belajar dan karakteristik peserta didik. (Nakayama M, Yamamoto H, 2007)

Oleh karena itu, tujuan dari penelitian ini adalah untuk mendapatkan informasi mengenai dampak Covid-19 terhadap implementasi pembelajaran daring yang diwacanakan pemerintah selama Covid-19 di tingkat Sekolah Dasar hususnya Madrasah Diniyah Nurul Ulum Mertak Tombok. Hal ini apakah pembelajaran daring yang ditawarkan atau ditetapkan oleh pemerintah bisa dilakukan dengan baik dan efektif atau sebaliknya.

\section{TINJAUAN PUSTAKA}

Perkembangan teknologi informasi dan komunikasi di era Industri 4.0 telah memiliki pengaruh yang besar terhadap proses pengajaran dan pembelajaran. Kemudahan akses teknologi telah digunakan oleh para pengajar untuk meningkatkan kualitas pendidikan. Seperti yang telah disampaikan oleh Keengwe \& Georgina dalam penelitiannya telah menyatakan bahwa perkembangan teknologi memberikan perubahan terhadap pelaksanaan pengajaran dan pembelajaran (Keengwe \& Georgina, 2012). Teknologi informasi dapat diterima sebagai media dalam melakukan proses pendidikan, termasuk membantu proses belajar mengajar, yang juga melibatkan pencarian referensi dan sumber informasi (Wekke \& Hamid, 2013).

Menurut Lashley (2014) penggunaan teknologi yang tersedia disekitar kita apabila diimbangi dengan diskusi dan panduan maka akan menjadi alat pengembangan keterampilan berpikir tingkat tinggi. Perkembangan teknologi ini memudahkan penggunaan internet untuk mengakses materi pembelajaran, berinteraksi dengan konten, instruktur, dan pelajar lain; dan untuk mendapatkan dukungan selama proses belajar, untuk memperoleh pengetahuan, untuk membangun pribadi makna, dan tumbuh dari pengalaman belajar. Umumnya, setiap tenaga pengajar di sekolah-sekolah dapat memiliki pertimbangan sendiri untuk memilih model pembelajaran mana yang dianggap paling cocok untuk diselenggarakan pada pembelajaran peserta didiknya.

Proses pembelajaran tatap muka (Luring) di Indonesia tidak dilaksanakan karena adanya pandemi Covid-19. Coronavirus itu sendiri adalah keluarga besar virus yang menyebabkan penyakit mulai dari gejala ringan sampai berat. Ada setidaknya dua jenis corona virus yang diketahui menyebabkan penyakit yang dapat menimbulkan gejala berat. Coronavirus Diseases 2019 (Covid-19) adalah penyakit jenis baru yang belum pernah diidentifikasi sebelumnya pada manusia. Tanda dan gelaja umum infeksi Covid-19 antara lain gejala gangguan pernapasan akut seperti demam, batuk, dan sesak napas. Masa inkubasi ratarata 5-6 hari dengan masa inkubasi terpanjang 14 hari. Pada tanggal 30 Januari 2020 WHO telah menetapkan sebagai kedaruratan kesehatan masyarakat yang meresahkan 
dunia. Pada tanggal 2 Maret 2020, Indonesia melaporkan kasus konfirmasi Covid-19 sebanyak 2 kasus. Sampai dengan tanggal 16 Maret 2020 ada 10 orang yang dinyatakan positif corona. (Yurianto, Ahmad, Bambang Wibowo, 2020). Sehingga Alternatif pembelajaran yang digunakan adalah pembelajaran daring.

\section{METODE PENELITIAN}

Metode penelitian ini menggunakan metode penelitian deskriptif kualitatif. Tujuan penelitian ini adalah menggambarkan pembelajaran daring yang diselenggarakan di tingkat Sekolah Dasar atau yang setara dengannya sebagai upaya dalam menekan mata rantai penyebaran Covid-19 di lingkungan Pendidikan Sekolah Dasar. Arikunto (2010) Penelitian deskriptif merupakan penelitian yang bertujuan untuk mengetahui keadaan dan kondisi yang mana hasilnya dijelaskan dalam bentuk laporan penelitian. Penelitian dilakukan dengan terlebih dahulu mengadakan survey kepada siswa dan lembaga mengenai penerapan pembelajaran daring.

\section{HASIL DAN PEMBAHASAN}

Penyebaran virus corona ini pada awalnya sangat berdampak pada dunia ekonomi yang mulai lesu, tetapi kini dampaknya dirasakan juga oleh dunia pendidikan. Kebijakan yang diambil oleh banyak negara termasuk Indonesia dengan meliburkan seluruh aktivitas pendidikan, membuat pemerintah dan lembaga terkait harus menghadirkan alternatif proses pendidikan bagi peserta didik yang tidak bisa melaksanakan proses pendidikan pada lembaga pendidikan.

Aktivitas yang melibatkan kumpulan orang-orang kini mulai dibatasi seperti bersekolah, bekerja, beribadah dan lain sebagainya. Pemerintah sudah menghimbau untuk bekerja, belajar, dan beribadah dari rumah untuk menekan angka pasien yang terpapar Covid-19. Menteri Nadiem Anwar Makarim menerbitkan Surat Edaran Nomor 3 Tahun 2020 pada Satuan Pendidikan dan Nomor 36962/MPK.A/HK/2020 tentang.
Pelaksanaan Pendidikan dalam Masa Darurat Coronavirus Disease (Covid-19) dalam hal ini pemerintah menawarkan dan menetapkan pembelajaran dilakukan dengan bebarapa cara yakni secara daring (online) dalam rangka pencegahan penyebaran coronavirus disease (Covid-19).

Perubahan iklim pembelajaran yang ditawarkan pemerintah tentu akan memberikan efek samping terhadap proses pembelajaran yang mana sebelumnya peserta didik dalam melakukan proses pembelajaran dengan tatap muka atau feed back antara guru dan siswa.

Adanya perubahan baru proses pembelajaran selama Covid-19 (Menteri Pendidikan, 2020) mengemukakan kelebihan dalam melakukan pembelajaran online untuk mengurangi penyebaran Covid-19 secara masif, salah satunya adalah meningkatkan kadar interaksi antara peserta didik dengan gurunya, pembelajaran dapat dilakukan dimana dan kapan saja (time and place flexibility), Menjangkau peserta didik (siswa) dalam cakupan yang luas (potential to reach a global audience), dan mempermudah penyempurnaan dan penyimpanan materi pembelajaran (easy updating of content as well as archivable capabilities) (Siahaan, 2002 dalam (Waryanto, 2006))

Pada dasarnya pembelajaran daring sebagaimana telah dibahasa sebelumnya sebenarnya memberikan dampak positif bagi dunia pendidikan kita saat ini yakni dengan adanya kemudahan bagi pendidik dan peserta didik dalam lingkup kombinasi pendidikan untuk bisa diterapkan di setiap lembaga pendidikan terutama di sekolah-sekolah. Namun dalam konteks ini, pembelajaran daring yang sedang diterapkan sebelumnya harus dikaji secara mendalam, kenapa hal ini sangat perlu, disebabkan karena lembaga pendidikan atau keadaan geografis dan demografis masyarakat indonesia berbedabeda dengan fasilitas sekolah dan keadaan dimana para peserta didik tinggal. Asumsi ini lebih tepat jika pembelajaran daring (online) akan efektif jika dilaksanakan dengan fasilatias yang memadai dan jaringan internet yang kuat untuk mengakses materi-materi 
pembelajaran yang diberikan oleh guru mereka, sehingga tidak terkendala pada perangkat, jaringan ataupun kuota internet.

Pembelajaran yang ditawarkan oleh pemerintah masih banyak menuai problematika dilapangan dan bisa kita lihat/rasakan sampai saat ini. Dari beberapa hasil temuan yakni siswa belum memiliki pengalaman atau budaya belajar jarak jauh karena selama ini sistem belajar dilaksanakan adalah melalui tatap muka, murid terbiasa berada di sekolah untuk berinteraksi dengan teman-temannya, bermain dan bercanda gurau dengan teman-temannya serta bertatap muka dengan para gurunya, dengan adanya metode pembelajaran jarah jauh membuat para murid perlu waktu untuk beradaptasi dan mereka menghadapi perubahan baru yang secara tidak langsung akan mempengaruhi daya serap belajar mereka. Dampak selanjutnya juga dirasakan oleh orang tua yaitu kendala yang dihadapi para orang tua adalah adanya penambahan biaya pembelian kuota internet dan kebutuhan alat teknologi yang lebih canggih.. oleh karena itu tingkat penggunaaan kuota internet akan bertambah dan akan menambah biaya pengeluaran orang tua.

Dampak yang dirasakan guru yaitu tidak semua mahir menggunakan teknologi internet atau media sosial sebagai sarana pembelajaran beberapa guru yunior belum sepenuhnya mampu menggunakan perangkat atau fasilitas untuk penunjang kegiatan pembelajaran online dan perlu pendampingan dan pelatihan terlebih dahulu. Jadi, dukungan dan kerjasama orang tua demi keberhasilan pembelajaran sangat dibutuhkan. Komunikasi guru dan sekolah dengan orang tua harus terjalin dengan lancar. Dari berbagai permasalah diatas, jika itu terpenuhi maka pembelajaran daring bisa berjalan dengan efektif.

Tatepi bagaimana dengan kondisi sebaliknya yang saat ada beberapa tempat dimana akses jaringan terutama dipedesaan yang jauh dari perkotaan dengan tingkat intensitas jaringan yang terbatas (tidak kuat), tentu pembelajaran daring akan mengalami hambatan. Kondisi semacam ini penulis temukan dimana proses pembelajaran daring tidak berjalan sebagaimana diharapkan yakni beberapa sekolah yang berada di Desa Mertak Tombok hususnya Madrasah Ibtidaiyah Nurul Ulum Mertak Tombok. sejak mewabahkanya Pandemi Covid-19 telah berdampak besar pada proses pembelajarannya.

Faktor-faktor yang menyebabkan pembelajran daring di Madrasah Ibtidaiyah Nurul Ulum Mertak Tombok tidak berjalan dengan efektif sebagaimana asumsi pemerintah bahwa pembelajaran daring akan berjalan lancar di setiap jejang pendidikan dan di semua daerah di seluruh Nusantara.

Asumsi semacam ini ternyata berbanding terbalik dari apa yang diharapkan ternyata di sebuah madrasah hususnya Madarasah Ibtidaiyah Nurul Ulum Mertak Tombok sangat minim keterlaksanaanya, dijumpai beberapa faktor diantaranya:

1. Faktor pertama terbatasnya media yang digunakan. Media yang dimaksud adalah gawai (HP) atau laptop untuk bisa mengakses mata pelajaran yang diberikan oleh guru-guru mereka. Ketidak mampuan para wali murid untuk membeli gawai atau laplop menjadi problematika penerapan pembelajaran daring selama pandemi. Kendala ini dialami oleh $76 \%$ siswa terhusus bagi orang tua yang tidak bisa memfasilitasi anak-anaknya untuk bisa memiliki perangkat tersebut. Pengadaan perangkat-perangkat tersebut bagi sebagian wali murid terasa sulit disebabkan oleh faktor dampak Covid-19 yang menjadikan ekonomi sementara menjadi lesu, ditambah harga gawai yang cukup mahal sehingga orang tua wali murid sedikit sulit untuk bisa mendampingi anak-anak mereka dalam pembelajaran daring yang dicanangkan pemerintah saat ini.

2. Faktor kedua adalah jaringan internet yang tidak bagus (lemot). Tidak kuatnya akses jaringan internet juga menjadi kendala utama bagi orang tua wali murid dan guru untuk bisa menerapkan pendidikan berbasis jaringan. Keterbatasan ini disebabkan oleh faktor geografis pedesaan dengan akses internet yang terbatas sehingga tidak 
memungkinkan bisa terlaksana pembelajaran secara daring.

3. Kuota yang terbatas. Kuota juga merupakan fasilitas yang harus ada ketika pembelajaran daring akan diterapkan. Namun bagi wali murid keterbatasan kuota ini juga menjadi permasalahan yang tidak bisa dipandang ringan, karena dengan adanya kouta inilah pembelajaran daring bisa terealisasikan dengan efektif. Ditambah lagi isu pemberian kuota oleh pemberintah kepada lembaga tidak terealisasaikan. Berdasarkan hasil temuan dan pengakuan dari beberapa wali murid dan guru, sampai saat ini belum ada bantuan kuota bagi peserta didik untuk bisa melaksanakan pembelajaran secara daring selama Covid-19.

4. Gaptek Teknologi. Kasus ini hampir dialami oleh sebagian wali murid terutama anak-anak yang senyatanya secara aflikatif belum sepenuhnya bisa memanfaatkan gawai secara baik sebagai sarana belajar mereka. Disamping itu faktor orang tua yang kurang pengetahuan dengan teknologi saat ini memungkinkan pembelajaran daring tidak bisa terealisasikan sebagaimana harapan pemerintah untuk peserta didik bisa belajar sebagaimana biasanya sehingga pembelajaran daring bagi peserta didik Madrasah Ibtidaiyah Nurul Ulum Mertak Tombok secara aplikatif tidak terealisasi Jadi realisasi pembelajaran daring yang ditawarkan oleh pemerintah selama pandemi Covid-19 berdasarkan permasalah tersebut diatas dan dengan temuan dilapangan sekolah tidak menerapkan pembelajaran daring.

Selain daring, sistem pembelajaran luring juga merupakan tawaran dari pemerintah. Luring inilah yang dimanfaatkan sebagai cara atau jalan untuk bisa melakukan proses pembelajaran dengan kalaborasi metode didalamnya. Istilah luring adalah kepanjangan dari "luar jaringan" sebagai pengganti kata offline. Kata "luring" merupakan lawan kata dari "daring". Dengan demikian, pembelajaran luring dapat diartikan sebagai bentuk pembelajaran yang sama sekali tidak dalam kondisi terhubung jaringan internet maupun intranet. Sistem pembelajaran luring (luar jaringan) artinya pembelajaran dengan memakai media, seperti televisi dan radio. Jika peserta didik mengerjakan tugas di Microsoft Word dan tidak menyambungkannya dengan jaringan internet, maka itu adalah contoh aktivitas luring dan Jika siswa melakukan offline conference dengan bertemu secara langsung tanpa menggunakan internet, hal itu adalah contoh aktivitas luring.

Bagi satuan pendidikan yang menerapkan pembelajaran luring maka guru dalam proses pembelajaran tersebut membuat strategi dalam memfasilitasi PJJ tersebut dengan menggunakan media buku, modul, dan bahan ajar dari lingkungan sekitar dan menyusun waktu pembelajaran dan pengumpulan hasil belajar yang disepakati dengan peserta didik, orang tua, dan atau sesuai dengan kondisi.

Sebelum pembelajaran dilaksanakan guru dianjurkan untuk menyiapkan RPP dan menyiapkan bahan ajar, jadwal dan penugasan kemudian mengirimkannya ke peserta didik atau orang tua sesuai dengan ketentuan yang berlaku dan mengikuti protokol kesehatan.

Kemudian memastikan semua peserta didik telah mendapatkan lembar jadwal dan penugasan, serta mengkondisikan waktu pengambilan tugas setiap sekali sepekan di akhir minggu atau disebarkan melalui media komunikasi yang tersedia. Pada saat pembelajaran luring guru dibantu orang tua atau wali dari peserta didik dengan jadwal dan penugasan yang telah diberikan dengan cara berkolaborasi. Guru juga dapat melakukan kunjungan ke rumah peserta didik untuk melakukan pengecekan dan pendampingan belajar namun tetap wajib melakukan prosedur pencegahan penyebaran Covid-19 serta tetap melaksanakan doa bersama sebelum melaksanakan pembelajaran. Setelah kegiatan pembelajaran guru memastikan setiap peserta didik mengisi lembar aktivitas sebagai bahan pemantauan belajar harian. Guru orang tua atau wali dari peserta didik memberikan tanda tangan pada sesi belajar yang telah tuntas di lembar pemantauan 
harian, memastikan penugasan diberikan sesuai jadwal dan meminta untuk dikumpulkan setiap akhir minggu sekaligus mengambil jadwal dan penugasan untuk pekan berikutnya.

Jadi, Dalam proses pembelajaran daring dan luring ada beberapa kesulitan yang dihadapi siswa, antara lain:

Jaringan internet yang lemot. Sistem pembelajaran daring dan luring dapat berjalan efektif jika jaringan internetnya bagus. Sebaliknya, ketika jaringan internetnya jelek/buruk, maka secara otomatis proses Kegiatan Belajar Mengajar (KBM) online pasti terhambat.

Sistem pembelajaran daring dan luring tentu tidak seefektif pembelajaran di sekolah. Hal ini terjadi karena beberapa faktor. Misalnya pengurangan jam mengajar. Guru-guru yang biasanya mengajar 4 jam di sekolah, terpaksa hanya mengajar selama satu jam. Dampak selanjutnya, peserta didik akan kesulitan memahami materi yang banyak dalam waktu yang relatif singkat. Apalagi berhadapan dengan mata pelajaran program Science. Keempat pelajaran ini tentunya membutuhkan waktu yang cukup lama karena banyak penurunan rumus. Itu artinya, waktu satu jam sangat tidak cukup

Karena mata pelajaran eksak seperti matematika, dianggap sebagai pelajaran yang sulit karena karakteristik matematika yang bersifat abstrak, logis, sistematis, dan penuh dengan lambang serta rumus yang membingungkan.

\section{KESIMPULAN}

Berdasarkan hasil penelitian ini, dampak dari Covid-19 telah memberikan efek yang cukup signifikan terhadap pembelajaran di Madrasah Ibtidaiyah Nurul Ulum Mertak Tombok bahwa problematika yang dihadapi dengan tidak bisa menggunakan pembelajaran daring sebagai solusi kegiatan proses belajar mengajar di sekolah disebabkan oleh bebarapa faktor seperti, jaringan, media, dan kuoata. Akan tetapi metode luring bisa dimanfaatkan sebagai upaya meminimalisir dampak buruk tidak terealisasinya proses belajar mengajar selama pandemi Covid-19 dengan bekerjasama bersama orang tua dalam mendapingi peserta didik belajar dengan keaadaan dan waktu yang terbatas.

Jadi problematika yang dihadapi oleh peserta didik dan guru dalam proses kegiatan belajar mengajar terletak pada perangkat atau prasarana pembelajaran yang dibutuhkan selama Covid-19 seperti gawai (hp, Laptop) dan lain sebagainya.

\section{SARAN}

Untuk kelancaran pelaksanaan kegiatan pembelajaran daring pemerintah harus lebih peka melihat kondisi/maupun keadaan sekolah seperti tersedianya fasilitas yang memadai untuk pelaksanaan pembelajaran daring dan melihat kemampuan masyarakat lebih khusus pada bidang ekonomi. Untuk itu anggaran biaya pendidikan di masa pandemi Covid-19 dinaikkan..

\section{DAFTAR PUSTAKA}

Arnesti, N., \& Hamid, A. (2015). Penggunaan Media Pembelajaran Online Offline Dan Komunikasi Interpersonal Terhadap Hasil Belajar Bahasa Inggris. Jurnal Teknologi Informasi \& Komunikasi Dalam Pendidikan, 2(1). https://doi.org/10.24114/ jtikp.v2i1.3284

Arsyad, Azhar. (2011). Media Pembelajaran. Jakarta: Penerbit Rajawali Pers.

Basori, B. (2017). Efektifitas Komunikasi Pembelajaran Online Dengan Menggunakan Media E-Learning Pada erkuliahan Body Otomotif. Jurnal Ilmiah Pendidikan Teknik Dan Kejuruan, 7(2), 39-45. https://doi.org/10.20961/jiptek.v7i2.1 2722.

Sriwihajriyah, N. ; Ruskan, E. L. ;, \& Ibrahim, A. (2012). Sistem pembelajaran dengan e-learning untuk persiapan ujian nasional pada SMA Pusri Palembang. Jurnal Sistem Informasi (JSI), 4(1), 450449. 
Waryanto, N. H. (2006). On-line Learning Sebagai Salah Satu Inovasi Pembelajaran. In Pythagoras (Vol. 2, Issue 1, 10-23). http://staff.uny.ac.id/ sites/default/files/132304807/Online Learning sebagai Salah Satu Inovasi Pembelajaran.pdf.

Wekke, I. S., \& Hamid, S. (2013). Technology on Language Teaching and Learning: A Research on Indonesian Pesantren. Procedia Social and Behavioral Sciences, 83, 585-589.

https://doi.org/10.1016/J.SBSPRO.2 $\underline{013.06 .111}$

Yurianto, Ahmad, Bambang Wibowo, K. P. (2020). Pedoman Pencegahan Dan Pengendalian Coronavirus Disease (Covid-19) (M. I. Listiana Azizah, Adistikah Aqmarina (ed.)). 